The mean deficits in PEF in men and women smoking fewer than 20 cigarettes a day were $48 \cdot 1$ and $47.4 \mathrm{l} / \mathrm{min}$, respectively. In men smoking 20 or more a day the mean deficit was $73.3 \mathrm{l} / \mathrm{min}$. A smaller but still significant deficit $(27 \cdot 8 \mathrm{1} / \mathrm{min})$ was found in male exsmokers of 20 or more cigarettes a day, whereas in the male and female ex-smokers of fewer than 20 cigarettes a day no significant reduction of PEF was present.

Even in the group of 60 men who were currently smoking 20 or more cigarettes a day only five had observed values that were more than $150 \mathrm{l} / \mathrm{min}$ below predicted.

\section{Discussion}

Other workers have drawn attention to the paucity of knowledge concerning ventilatory function in elderly people. ${ }^{3-5}$ Reference values which are commonly used for predicting PEF or $\mathrm{FEV}_{1}$ above the age of 60 have been derived by extrapolation of linear regressions in younger subjects. ${ }^{6-10}$ For instance, those which Cotes advocated for predicting PEF in men" were obtained in a series containing only three men aged over $60,{ }^{9}$ and those for women were from a series of 64 women whose ages ranged between 19 and $82^{10}$; both series included a high proportion of smokers.

Owing to the comparatively small number of lifelong non-smokers aged over $60,{ }^{13}$ particularly among men, most other workers who have investigated ventilatory function in the elderly have included smokers and exsmokers, provided that they appeared healthy, denied expectoration, and gave no history of respiratory or cardiac disease. ${ }^{3512-15}$ Even so, in one study of $\mathrm{FEV}_{1}$ in randomly selected and apparently healthy men aged $62-90$, of whom $92 \%$ were or had been smokers, persistent cough and phlegm were found to be present in one third. ${ }^{3}$

In a survey of PEF and $F_{1} V_{1}$ in subjects aged 65-94 only three of 83 men were non-smokers ${ }^{13}$ whereas in a more recent study of 46 men aged $60-85$ fewer than a third had never smoked. ${ }^{\text {s }}$

We did not adopt the frequently used convention of expressing observed values as percentages of predicted, as there is no physiological or statistical validity in regarding a given percentage of predicted as representing the lower limit of normal. ${ }^{16}$ Instead, we expressed our findings of PEF as differences between subjects' observed and predicted values.

Other workers have shown that the PEF can discriminate between "healthy" men aged over 50 and those with "mild" chronic bronchitis. ${ }^{18}$ Our findings, however, indicate that smoking can cause significant impairment of ventilatory function in the absence of hypersecretion of mucus.
It was not a principal aim of this study to investigate the role of smoking in the pathogenesis of chronic bronchitis; indeed, our selection criteria excluded people with even "simple chronic bronchitis". ${ }^{19}$ Nevertheless, our finding that the reduction of PEF in smokers and former heavy smokers, though highly significant, was much smaller than that which is characteristic of patients with advanced chronic bronchitis or emphysema suggests that other factors besides smoking are concerned in the development of severe, irreversible airflow obstruction and dyspnoea. It seems probable that these include hypersecretion of mucus in small airways and susceptibility during childhood or adulthood to recurrent lower respiratory tract infection or asthma. By reason of the selection criteria that we used, none of these factors had been operative in the subjects whom we studied.

We thank Miss Deborah Johnson and Mrs Marion Rickman for their help in analysing the data, and the Rudolf Friedlaender Memorial Trust, the Department of Health and Social Security, the Royal College of General Practitioners, and Allen and Hanbury's Ltd for grants which supported this study.

1 Nunn AJ, Gregg I. New regression equations for predicting peak expiratory flow in adults. Br Med f 1989;298:1068-70.

2 Gregg I. A study of the causes of progressive airways obstruction in chronic bronchitis. In: Proceedings of llth Aspen emphysema conference. Arlington, Virginia: US Department of Health, Education and Welfare, 1969:235-46.

3 Milne JS, Williamson J. Respiratory function tests in older people. Clin Sci 1972:42:371-81.

4 Morris JF, Koski A, Johnson LC. Spirometric standards for healthy nonsmoking adults. Am Rev Respir Dis 1971;103:57-67.

5 Schmidt CD Dickman ML, Gardner RM, Brough FK Spirometric standards for healthy elderly men and women. Am Rev Respir Dis 1973;108:933-9.

6 Gregg I, Nunn AJ. Peak expiratory flow in normal subjects. Br Med $\mathrm{f}$ 1973; iii:282-4.

7 Kory RC, Callahan R, Boren HG, Syner JC. The Veterans Administration Army Cooperative study of pulmonary function. 1. Clinical spirometry in normal men. Am f Med 1961;30:243-58.

8 Berglund E, Birath G, Biore J, et al. Spirometric studies in normal subjects. Forced expirograms in subjects between 7 and 70 years of age. Acta Med Scand 1963;173:185-92.

9 Leiner GC, Abramowitz S, Small MJ, Stenby VB, Lewis WA. Expiratory peak flow rate. Standard values for normal subjects. Use as a clinical test of ventilatory function. Am Rev Respir Dis 1963;88:644-51.

10 Pelzer AM, Thomson ML. Expiratory peak flow. Br Med f 1964;ii: 123.

11 Cotes JE. Lung function: assessment and application in medicine. 4th ed. Oxford Blackwell Scientific, 1979.

12 Ericsson $\mathrm{P}$, Irnell $\mathrm{L}$. Spirometric studies of ventilatory capacity in elderly people. Acta Med Scand 1969;185:179-84.
pericsson P, Irnell L. Spirometric studies of

13 Caird FI, Akhtar AJ. Chronic respiratory disease in the elderly: a population study. Thorax 1972;27:764-8

14 Burr ML, Phillips KM, Hurst DN. Lung function in the elderly. Thorax 1985; $40: 54-9$

15 Fowler RW, Pluck RA, Hetzel MR. Maximal expiratory flow-volume curve in Londoners aged 60 years and over. Thorax 1987;42:173-82.

16 Sobol BJ, Sobol P. Per cent of predicted as the limit of normal in pulmonary function testing: a statistically valid approach. Thorax 1979;34:1-3.

17 Miller MR, Pinock AC. Predicted values: How should we use them? Thorax 1988:43:265-7.

18 Flint FJ, Khan MO. Clinical use of peak flow meter. Br Med $\mathcal{f}$ 1962;ii:1231-3.

19 Medical Research Council. Definition and classification of chronic bronchitis for clinical and epidemiological purposes. Lancet 1965;i:775-9.

(Accepted 27 February 1989)
Department of Urology, Southmead Hospital, Bristol K M Desai, CHM, senior registrar J C Gingell, FRCS, consultant

Correspondence to: Mr Desai.

BrMed F 1989;298:1072-3

\section{Hazards of long distance cycling}

\section{K M Desai, J C Gingell}

We report an unusual complication of long distance cycling that occurred in a young man unaccustomed to riding more than a few kilometres.

\section{Case report}

An otherwise healthy 27 year old man was referred to us because of secondary erectile impotence. He had enjoyed normal sexual function before taking part in a two day, $209 \mathrm{~km}$ bicycle race five months previously. He had ridden on a narrow, hard leather saddle and had experienced severe perineal pain and urgency of micturition after cycling about $32 \mathrm{~km}$, which had forced him to stop at a service station. While voiding he had noticed that his penis was completely shrivelled and had lost all sensation. The pain subsided after a few minutes, enabling him to continue cycling. $\mathrm{He}$ managed to finish the race despite recurrence of perineal and gluteal pain causing further brief stops. After the race he suffered a total loss of erections for about three weeks. By the time he was seen in our clinic his erections had gradually improved, but they still lacked full rigidity and were only briefly sustained. $\mathrm{He}$ also complained of impaired penile sensation, though this too had partially recovered. Orgasmic sensation and ejaculation were allegedly normal.

Results of clinical examination and routine analysis of urine, a random blood glucose concentration, and serum testosterone and prolactin concentrations were normal. An intracavernosal injection of $15 \mathrm{mg}$ 
papaverine resulted in a fully rigid erection lasting almost 90 minutes. Computerised analyses of both dorsal and cavernosal arterial Doppler waveforms,' recorded during the tumescent phase, also proved normal. Thus there was no evidence of penile haemodynamic disturbance. Electrophysiological elicitation of the bulbocavernosus reflex, whose afferent and efferent limbs are composed of somatic pudendal nerves relayed through sacral segments 2,3 , and 4 , showed a normal latency of $26 \mathrm{~ms}$ to the onset of response (mean (2 SD) value for our laboratory $28 \cdot 1$ $(5 \cdot 7) \mathrm{ms}) .^{2}$ The mean (of three measurements) sensory perception threshold of the dorsal nerve of the penis was raised at 110 volts (mean ( $2 \mathrm{SD}$ ) value for our laboratory $64 \cdot 2(23 \cdot 2)$ volts) ${ }^{2}$

Because a spontaneous improvement was already occurring he was treated conservatively. Three months later he reported complete resolution of his symptoms and a return to full potency.

\section{Comment}

We have found only one other report of temporary erectile impotence after prolonged cycling. ${ }^{3}$ The likeliest cause of this complication in our patient seems to be an ischaemic neuropathy of the dorsal (sensory) and cavernous (vasomotor) nerves of the penis induced by compression of the penile crura, to which they are anatomically related, against the pubic bone by the hard narrow saddle. The raised sensory threshold of the dorsal nerve, even five months after the injury, supports this hypothesis. Penile and scrotal hypoaesthesia has been shown in men who have ridden on such saddles, ostensibly as a result of pudendal neuritis. ${ }^{4} \mathrm{~A}$ further factor in our patient may have been a transient compromise in penile arterial inflow. This is suggested by one study which showed a significant fall in the penile blood pressure of 20 healthy men who sat on an unpadded cycle seat for five minutes. ${ }^{5}$ The vulnerability of the penile neurovascular supply to compression leads us to believe that short term erectile impotence may be much more common in long distance cyclists than is recognised.

We thank Mr W B Peeling, consultant urologist at St Woolos Hospital, Newport, Gwent, for referring this case.

1 Desai KM, Gingell JC, Skidmore R, Follett DH. The application of computerised penile arterial waveform analysis in the diagnosis of arteriogenic impotence-an initial study in potent and impotent men. $\mathrm{Br} \mathcal{J} U$ rol 1987;60:450-6.

2 Desai KM, Dembny K, Morgan MH, Gingell JC, Prothero D. The neurophysiological investigation of diabetic impotence - are sacral response studies physiological investigation of diabe
of value? Br $\mathcal{\text { Urol }}$ 1988;61:68-73.

3 Soloman S, Cappa KG. Impotence and bicycling. A seldom reported connection. Postgrad Med 1987;81:99-102.

Goodson JD. Pudendal neuritis from biking. N Engl f Med 1981;304:365.

5 Kerstein MD, Gould SA, French-Sherry E, Pirman C. Perineal trauma and Kerstein MD, Gould SA, French-Sherry E, P.
vasculogenic impotence. F Urol 1982;127:57.

(Accepted 13 February 1989)

\title{
Social adversity and perinatal complications: their relation to postnatal depression
}

\author{
Alan Stein, Peter J Cooper, \\ Elizabeth A Campbell, Ann Day, \\ Patricia M E Altham
}

\begin{abstract}
Department of Psychiatry, University of Oxford, Warneford Hospital, Oxford OX3 7JX Alan Stein, MRCPSYCH, Wellcome Trust lecturer Elizabeth A Campbell DPHIL, research fellow Ann Day, research
\end{abstract} administrator

Departments of Psychiatry, Pure Mathematics, and Mathematical Statistics, University of Cambridge, Cambridge

Peter J Cooper, DPHIL, lecturer in psychopathology Patricia M E Altham, PHD, lecturer in mathematical statistics

Correspondence to: Dr Stein.

Br Med f 1989;298:1073-4
Postnatal depression, long acknowledged as an important mental health problem for mothers, may also have serious consequences for the child. We looked at two sets of variables of possible aetiological importance to postnatal depression that have received surprisingly little attention - namely, the role of perinatal complications and factors reflecting socioeconomic disadvantage.

\section{Patients, methods, and results}

We recruited 483 women over nine months in 1982 from the antenatal clinic and booking diary of the John Radcliffe Hospital, Oxford, by approaching every second expectant mother in the last trimester of her pregnancy. ${ }^{2}$ The women were interviewed at home six to eight weeks before their expected date of delivery. Social and socioeconomic data were obtained from a semistructured interview. Perinatal data were obtained from the Oxford obstetric data system and included information on length of each stage of labour, antepartum haemorrhage, abnormal presentation, obstetric intervention, perineal and other tears, postpartum haemorrhage, and any other complications at any stage of labour. Data on the infant included information on gestational age, birth weight, neonatal asphyxia, congenital abnormalities, other complications, and admission to the special care baby unit.

Of the 483 women seen antenatally, 460 were available for follow up three months postnatally. Twenty nine women were psychiatrically disturbed at the antenatal assessment, of whom two were unavailable for follow up. Using the general health questionnaire $^{3}$ three months postnatally to screen for probable psychiatric disorder and the Montgomery Asberg depression scale and the present state examination ${ }^{4}$ interview to examine mental state we identified 31 women as having non-psychotic psychiatric disturbance (present state examination index of definition $\geqslant 5$ ), of whom seven had been disturbed antenatally. ${ }^{2}$ The 24 women with disorders of postnatal onset were all suffering from depression of at least moderate severity as assessed by the Montgomery Asberg depression scale. None were sufficiently disturbed to require admission.

None of the perinatal factors investigated were related to postnatal depression. Because this surprised us we carried out further analyses to determine whether perinatal factors were related to less severe psychological symptoms with a low threshold for disturbance (general health questionnaire score $\geqslant 12$ ). No relation was found.

In contrast, significant relations were found between depression of postnatal onset and certain social factors (table)- namely, having a low family income, neither partner being employed, and not having a confidant. Logistic regression analysis ${ }^{5}$ showed that only two

Relation between social factors and postnatal depression $\star$

\begin{tabular}{|c|c|c|c|}
\hline Social factor & $\begin{array}{c}\text { No (\%) with } \\
\text { postnatal } \\
\text { depression } \\
(\mathrm{n}=24)\end{array}$ & $\begin{array}{c}\text { No }(\%) \text { without } \\
\text { postnatal } \\
\text { depression } \\
(n=410)\end{array}$ & p Value \\
\hline Working class & $12(50)$ & $140(35) \dagger$ & NS \\
\hline Low income $\ddagger$ & $10(42)$ & $67(16) \oint$ & $<0.01$ \\
\hline Neither partner employed\| & $7(29)$ & $46(11)$ & $<0.05$ \\
\hline No partner & $4(17)$ & $18(4)$ & NS \\
\hline No confidant & $5(21)$ & $14(3)$ & $<0.01$ \\
\hline Primiparous & $8(33)$ & $182(44)$ & NS \\
\hline$\geqslant 3$ Children & & $22(5)$ & NS \\
\hline
\end{tabular}

$\chi^{2}$ Or Fisher's exact probability test was used as appropriate

$\chi$ Or Fisher's exact probability test was used as appropriate. $\star$ All cases analysis

$\ddagger$ Total yearly family income $<£ 4000$ ( 1982 figures).

$\ddagger$ Total y
$\mathrm{S} n=408$

$\|$ Includes unemployed single mothers. 